\title{
Differentiating philosopher from statesman according to work and worth
}

This is the pre-peer version of an article that will appear in Polis, 2020. For all quotes, please refer to the published version.

Abstract: Plato's Sophist and Statesman stand out from many other Platonic dialogues by at least two features. First, they do not raise a ti esti question about a single virtue or feature of something, but raise the questions what sophist, statesman, and philosopher are, how they differ from each other, and what worth each should be accorded. Second, a visitor from Elea, rather than Socrates, seeks to addressed these questions and does so by employing what is commonly referred to as the method of collection and division. Some scholars have argued that this so-called method is value neutral and therefore unable to address the question how philosophy differs from sophistry and statesmanship according to worth. This article contends that the procedures of collection and division does not preclude the visitor from taking considerations of worth into account, but rather helps establish an objective basis for settling the main questions of the dialogue.

Keywords: Dialectic, collection and Division, Platonic Ontology, Value, Sophistry, Death of Socrates 
Plato's Sophist and Statesman constitute a prolonged inquiry into sophistry, political expertise, and philosophy that stands out from most inquiries found in other Platonic dialogues by at least two features.1 First, the questions guiding the inquiry and their interconnection are more complex than the questions found in many other dialogues; rather than raising a single ti esti question concerning a virtue or feature of something, the dialogues raise a ti esti question concerning sophistry, political expertise, and philosophy that is intimately related to the questions how the three activities are to be distinguished from each other and what worth we should accord to them. Second, the main interlocutor in the two dialogues, a visitor from Elea, conducts much of his inquiry by following two procedures, commonly referred to as the method of collection and division, to an extent unrivalled by any other dramatis persona in Plato.

Scholars disagree on the question how we should estimate the philosophical merits of this so-called method and on the question what view of sophistry, political expertise, and philosophy emerges from the dialogues. For while the visitor ostensibly defends the view that philosophy differs both from sophistry and political expertise (Soph. 217b1-4) and that collection and division are somehow needed to illuminate what they are (Soph. 218b6-c5 with

1 I wish to thank Vivil Valvik Haraldsen whose careful comments and suggestions always improve the quality of my work. Special thanks are due Ryan Balot, Hallvard Fossheim, and Vasilis Politis, who read and commented on various versions of the article; their helpful suggestions and criticism are much appreciated. I also wish to thank the participants at the conference "Democracy and its Rivals" at the University of Bergen and at a workshop on Plato's Statesman at the Trinity Plato Center, Trinity College Dublin, who commented on earlier versions of the paper. The article was written as part of the postdoctoral project DICTUM. This project has received funding from the European Union's Horizon 2020 research and innovation programme under the Marie SkłodowskaCurie grant agreement No 750263. 
218e2-219a2, Pol. 258b1-8), the questions whether these procedures are well suited to perform this task and how the visitor conceives of the three activities remain.

At least since the beginning of the 20 th century, most scholars have regarded the procedures as a method characteristic of the later Plato intended to provide real definitions or explanatory accounts of various things 2 and the definitions of sophistry and political expertise expressed in the two dialogues as successful.з Other scholars, however, have objected that the

\footnotetext{
${ }^{2}$ See J. Stenzel, Studien zur Entwicklung der Platonischen Dialektik von Sokrates zu Aristoteles (Breslau: Trewendt \& Granier, 1917), p. 2, pp. 45-54; F. MacDonald Cornford, Plato's Theory of Knowledge (London: Kegan Paul, 1935), pp. 170-172, pp. 184-187; R. Hackforth, Plato's Phaedrus (Cambridge: Cambridge University Press, 1952), pp. 134-137; W. K. C. Guthrie, A history of Greek Philosophy vol. V: The Later Plato and the Academy (Cambridge: Cambridge University Press, 1978), p. 33 and p. 130; P. Crivelli, Plato's Account of Falsehood (Cambridge: Cambridge University Press. 2012), pp. 13-22. Guthrie sensibly suggests that this method for arriving at definitions is nothing new but is rather 'the climax of a fairly long development, originating in the Socratic search for definitions', p. 130, a development that he suggests may even go further back, namely to the Hippocratic writings, pp. 27-29.

${ }^{3}$ See Cornford, Theory of Knowledge, p. 173; N. Notomi, The Unity of Plato's Sophist (Cambridge: Cambridge University Press, 1999), pp. 75-77. See also Crivelli, Account of Falsehood, p. 13 and p. 27.
} 
supposed method as used by the visitor is flawed, 4 of little philosophical importance, 5 or that Plato did not embrace it. 6 It has likewise been objected that the visitor fails to answer the question what sophist, statesman, and philosopher are in consequence of the alleged fact that his method disregards the worth of what is inquired into; for the difference between political phenomena such as sophistry, political expertise, and philosophy, it is assumed, cannot be understood adequately in isolation from their relative worth.7

This article defends the visitor's manner of inquiry with a particular emphasis on the question how he compares philosophy and political expertise, and argues for three interconnected claims. First, collection and division are procedures used to delimit sophistry

\footnotetext{
${ }^{4}$ See e.g. J. B. Skemp, Plato's Statesman (London: Routledge \& Kegan Paul), p. 18; H. R. Scodel, Diairesis and Myth in Plato's Statesman (Göttingen: Vandenhoeck \& Ruprecht), pp. 20-33; S. Rosen, Plato's Statesman: The Web of Politics (New Haven: Yale University Press, 1995), pp. 18-36; J. Lenkowski, 'Definition and Diairesis in Plato and Aristotle', The St. John's Review 56.1 (Fall 2014), pp. 47-64. See also L. Campbell, The Sophistes and the Politicus of Plato - with a Revised Text and English Notes (Oxford: At the Clarendon Press, 1867), 'Introduction to the Statesman', p. xii.

${ }^{5}$ G. Ryle, Plato's Progress (Cambridge: Cambridge University Press, 1966), pp. 136-141; S. Rosen, Plato's Sophist (New Haven: Yale University Press, 1983), p. 9. See also Campbell, Sophistes and Politicus, 'General Introduction', pp. x-xiii.
}

${ }^{6}$ See Rosen, Plato's Sophist, pp. 7-12; F. J. Gonzalez, 'The Eleatic Stranger - His Master's Voice?' in G A. Press (ed.), Who Speaks for Plato - Studies in Platonic Anonymity (Lanham: Rowman \& Littlefield Publishers, 2000), pp. 161181; D. Hyland, Questioning Platonism: Continental Interpretations of Plato (Albany: State University of New York Press, 2004), p. 25.

${ }^{7}$ See Rosen, Plato's Sophist, pp. 10-11, pp. 25-28, pp. 120-121; Gonzalez, 'His Master's Voice?', pp. 162-172; Hyland, Questioning Platonism, pp. 20-26; D. Ambuel, Image and Paradigm in Plato's Sophist (Las Vegas: Parmenides Publishing, 2007), p. xv. 
and political expertise sufficiently for the inquiry into their respective connections to philosophy to proceed, but they do not constitute a method in any strict sense nor are they aimed at providing full, explanatory accounts.8 Second, using these procedures does not preclude the visitor from taking considerations of worth into account in his inquiry but rather helps establish an objective basis for such considerations. Third, the procedures acquire a political significance because they help articulate a non-conventional ranking of the three types of expertise as regards their worth; in particular, they help support the view that political expertise, while important, is preoccupied primarily with our political existence and the virtues most closely associated herewith, moderation and courage, and that political expertise for this reason differs from, and is of lesser worth, than philosophy.

The view of collection and division argued for in this paper has some affinity to views of these procedures defended by Mary Louise Gill and by John L. Ackrill. With Gill it shares the conviction that the procedures are not meant to provide full answers to the ti esti questions pursued in the Sophist and the Statesman.9 With Ackrill it shares the view that the procedures should not be understood too narrowly, and, in particular, that the actual examples of them found in Plato are 'fragmentary contributions toward the full understanding the philosopher seeks', an understanding that both 'demand[s] insight' and aims to 'produce

\footnotetext{
${ }^{8}$ I take for granted without argument that a full account of something, according to Plato, needs to explain what that something is, that is, what is essence is; in order for a determination of something to be able to distinguish it from other things, in contrast, it merely needs to differentiate that something sufficiently well from other things without living up to the more rigid demands of a full account.

${ }^{9}$ See M. L. Gill, 'Division and Definition in Plato's Sophist and Statesman', in D. Charles (ed.), Definition in Greek Philosophy (Oxford: Oxford University Press, 2010), pp. 172-199.
} 
clarification'.10 In contrast to Ackrill and Gill, however, the paper pursues the question what relation exists between these procedures and the relative worth of what is inquired into. In contrast to other scholars who discuss this relation, such as Stanley Rosen, Drew Hyland and Francisco Gonzalez,11 the paper urges that the procedures help explicate the objective reasoning behind the visitor's evaluative judgements rather than prevent such judgements.

\section{I: The guiding questions of the Sophist and the Statesman and the visitor's task}

The question what sophistry, political expertise, and philosophy are emerges from a problem Socrates points to at the beginning of the Sophist. Confronted with the claim that the Eleatic visitor, whom Theodorus has brought along for the conversation, is 'very much a philosopher' (216a4), Socrates suggests that the kind (genos) 'philosopher' is no easier to discern (diakrinein) than the kind 'god' (216c2-4). He proceeds to explain this as follows. Philosophers, due to the ignorance of others, appear in all sorts of shapes; 'to some they appear to be in no way honorable and to others in every way worthy', sometimes appearing 'as statesmen and sometimes as sophists, and sometimes' as 'being in a totally mad condition' (216c4-d2).12 This problem leads Socrates to ask the visitor whether people in Elea consider sophist, statesman, and philosopher as one or two kinds, or, just as there are three names, as

\footnotetext{
${ }^{10}$ See J. L. Ackrill, 'In Defence of Platonic Divisions', in O. P. Wood and G. Pitcher (eds.), Ryle. Modern Studies in Philosophy (London: Palgrave, 1970), p. 387.

${ }^{11}$ See note 6 and 7 above.

12 Translations of the Sophist are from Plato: Sophist, translated, with introduction and glossary, by E. Brann, P. Kalkavage, and E. Salem (Newburyport: Focus Publishing, 1996), translations of the Statesman from Plato: Statesman, translated, with glossary, essay, and appendices, by E. Brann, P. Kalkavage, and E. Salem (Newburyport: Focus Publishing, 2012). The translations have sometimes been modified slightly without notice.
} 
three kinds (genê; 217a1-9)? The visitor responds by saying that people in Elea consider them to be three, but he adds that it is no small task to distinguish clearly what each of them is $(t i$ pot' estin; 217b1-4).

The opening scene of the Sophist thus presents us with three interconnected questions. Most prominent is the question what (ti esti) philosophy, sophistry, and political expertise are, a question motivated by the problem that philosophers are commonly confused with sophists and statesmen. This confusion raises a second question, namely how we are to distinguish (diorizein) the three from each other and whether the three names correspond to three kinds or not; it could be that true statesmen and philosophers are identical, a view suggested by Socrates in the Gorgias (521d6-8), or that philosophers and sophists are identical, a view apparently held by many in Plato's Athens.13 That distinguishing the three from each other is not the same task as giving a full account of each, even if both tasks are closely related, can be made plausible through the following consideration. In order to distinguish one thing from another, one need not be able to give a full account of the thing in question, even if, in order to give such an account, one probably needs to distinguish the thing to be defined from everything else. The third question we are presented with concerns the relative worth we should ascribe to these three types. In the Sophist Socrates suggests that the conflicting appearances of the philosopher is connected with the fact that different people appreciate his or her worth differently (216c4-8). At the beginning of the Statesman he indicates that this problem concerns all three types of expertise when he suggests that the three 'differ in honor by more than can be expressed in accordance with the proportions' of

\footnotetext{
${ }^{13}$ See M. Frede, 'The Literary Form of the Sophist', in C. Gill and M. M. McCabe (eds.), Form and Argument in Late Plato (Oxford: Oxford University Press, 1996), p. 147.
} 
the mathematical arts (257b2-4).14 This raises the question what worth each type should be ascribed.

That these questions have an existential and political import is underlined on the dramatical level of the dialogues by the fact that the inquiry of the Sophist and the Statesman unfolds the day after Socrates is first accused of corrupting the young and of disregarding the gods of the city.15 According to Plato's Apology this accusation in part results from the impression that Socrates is a sophist $(18 \mathrm{~b} 7-\mathrm{d} 2)$. The Meno, in contrast, suggests that the accusation results from a conflict between Socrates' perspective on virtue and education and a perspective thereon characteristic of democratically oriented gentlemen such as Socrates' accusers Anytus and Meletus, according to whom virtue is something any good citizen may teach to any other (compare Men. 92e3-95a1 with Apo. 24c10-25a11); Socrates' trial is, when seen from this perspective, the result at least in part of a political conflict concerning the question what virtue and education is.16 The motif of Socrates' trial thus brings the questions

\footnotetext{
${ }^{14}$ Strictly speaking, Socrates states that their respective honor differ more than accords with the proportions of 'your' arts, that is, those possessed by Theodorus; this could indicate that it is not mathematical proportions as such, but rather the limits of Theodorus' arts, that is at stake.

${ }^{15}$ For this dramatic feature of the two dialogues, compare Theaetetus 210d2-4 with Sophist 216a1-4.

${ }^{16}$ On the point that Meletus and Anytus represent the view that all good citizens are able to improve any other willing citizen, and that this view is closely related to the educational ideals of sophists such as Protagoras but stands in radical conflict with Socrates' view of virtue and education, see P. Steiner, Psyche bei Platon (Vandenhoeck \& Ruprecht, Göttingen, 1992), pp. 17-24.
} 
what sophistry, political expertise, and philosophy are, whether or not they differ from each other, and what worth should be accorded to them, into clearer focus.17

But we are left to wonder how we are to conceive of the connection between the question concerning their relative worth, on the one hand, and the questions what they are and whether and how they differ, on the other. It seems safe to suppose that Socrates is not suggesting that we need to settle the question concerning their worth before we settle the latter two questions. In other dialogues, at least, Plato lets his Socrates suggest that questions whether something has a certain quality or not must be decided by inquiring into what that something is. In the Gorgias he thus insists that one has to decide what rhetoric is before deciding what worth it has, in the Meno that one has to decide what virtue is before deciding whether it is teachable or not (Gorg. 448c4-9, 448d1-449a2, 451d7-8, 462c10-d2, Men. 71b37; see also Resp. 354b3-6). This does not imply, however, that the question whether something possesses a quality or not is left out of consideration entirely while pursuing the question what that thing is. The question whether rhetoric is noble or not continues to animate the inquiry into rhetoric in the Gorgias (262c8-9, 466a9-10), just as the question whether virtue can be taught or not continues to animate the inquiry of the Meno (86c7-d2). As we shall see, the question what worth we should accord to sophistry and, especially, political expertise and philosophy likewise continues to animate the inquiry into what they are in the Sophist and the Statesman.18

\footnotetext{
${ }^{17}$ See Guthrie, The later Plato, p. 122. For discussions of the way this motif affects the argument of the Sophist and the Statesman, see Hyland, Questioning Platonism, pp. 19-20, and, especially, J. Howland, The Paradox of Political Philosophy (Lanham: Rowman \& Littlefield, 1998).
} 
The visitor seeks to settle Socrates' problem in the two dialogues by setting out from the question what sophistry and political expertise are, respectively, not from the question what worth they have and we may conclude that this can be characterized as a move familiar from the so-called Socratic dialogues, not as a move especially characteristic of the visitor's supposedly 'value-neutral method', as some critics have suggested.19 In the Sophist the visitor suggests that the interlocutors must make clear through an account (logos) what ( $t i$ pot' esti) the sophist is (218b7-c1), since, to begin with, all they have in common is the name, while each of them may have 'his own private notion of the work (ergon)' called by that name (218c1-3), a problem the visitor later suggests arises because the apparent expertise of sophists is difficult to discern $(223 c 1-4,226 a 6-7$, see also 218c5-7). In the Statesman he makes a closely related point when he states that he and his interlocutor aim at clarifying the business (pragmateia) of the statesman (279a7-b1, 275e3-4), a task made difficult by the fact that the statesman's expertise is easily confused with other types of expertise (267e7-268c3, 279a1-5).20

That the visitor suggests that they should begin by focusing on the work or business performed by sophists and statesmen is important for a number of reasons. It shows that he is not interested in discussing the various individuals or groups of individuals commonly identified as sophists, statesmen, and philosophers, nor the worth they may traditionally be accorded; it is only the work they perform that matters. In the light of the problem pointed to by Socrates at the opening scene of the Sophist, this choice seems well

\footnotetext{
${ }^{19}$ See e.g. Gonzalez, 'His Master's Voice?', pp. 166-169.

${ }^{20}$ For the parallel between the inquiry of the Sophist and the Statesman on this point see M. Lane, Method and Politics in Plato's 'Statesman' (Cambridge: Cambridge University Press, 1998), pp. 46-47.
} 
motivated. For, one may argue, it is only if the three perform different types of work that we are justified in claiming that they differ from one another. Moreover, since the question what worth we should accord to each is contested, it could seem that the visitor's focus on work is also motivated by a desire to solve this problem in a non-arbitrary manner, since deciding what work they perform may seem to be the best way of doing so. Rather than following common, ambiguous, opinions about the worth of sophists, statesmen, and philosophers, the visitor, we may suppose, aims at deciding their worth solely on the basis of the importance of their work.

\section{The methodos of the visitor: differentiation and worth}

It is primarily in order to decide what work sophist and statesman perform that the visitor introduces the procedures of collection and division in the Sophist and the Statesman.21 We need not conclude, however, that these procedures are introduced in order to define sophist and statesman as several scholars have suggested, 22 at least if we by 'defining' mean 'giving a full account of what they are'. As pointed out, Socrates' initial problem gives rise to two different, if closely related, questions: a) what are sophist, statesman, and philosopher?, and b) how are we to distinguish between them? And while the two dialogues seem to aim at answering the first question, it is quite possible that collection and division is used only to help decide the second question - for the purpose of helping to answer the first question

\footnotetext{
${ }^{21}$ The visitor also employs collections and divisions for various other purposes, such as distinguishing five great kinds or types in the middle part of the Sophist (253b9-258e5) and two types of measure in the Statesman (see 283d4-5 with 284e2-285b6).

${ }^{22}$ See note 2 and 3 above.
} 
adequately. Whether or not the dialogues offer a final answer to the ti esti question, i.e. a full account of sophistry, statesmanship and philosophy, is another matter. The suggestion here is only that the procedures of collection and division do not provide such full accounts and are not intended to do so.

That this reading of the function of collection and division, at least in these dialogues, is preferable, can be seen from the fact that collections and divisions, while employed systematically throughout the first parts of the Sophist (219a4-236d3) and the Statesman (258b3-267c3), are used much more sparingly in the central parts of the dialogues. Here they are supplied with additional considerations, both ontological and methodical in nature, that the visitor explicitly states are called for in order to decide what sophistry or statesmanship are (e.g. Soph. 241c2-242b8, Pol. 268d5-e2, 277a3-d4). We may also note that the visitor never claims that collection and division are his preferred tools for inquiry tout court or that philosophy is identical with the use of a method as such; he merely introduces the procedures as helpful for answering the question what sophist and statesman are. Later he claims that the ability to distinguish correctly, i.e. to use collection and division correctly, belongs to the dialectician (Soph. 253d1-3), but this does not rule out that dialectic is more than an ability to use such procedures, nor that additional knowledge is required for the dialectician to distinguish correctly, for instance presuppositions about the nature of the soul, education and the like. Finally, as we shall see, collection and division aim at distinguishing something by comparing it to, and contrasting it with, other things. But this means that determinations arrived at through collection and division are relational determinations that take their bearing from what something is not; they are not positive determinations of something that look primarily at the intrinsic and non-relational nature of what they seek to determine. 
These considerations are not meant to question the importance of the procedures of collection and division, but rather to help us understand to what purpose the visitor introduces them. They serve an important purpose in the dialogues because they help distinguish the types of expertise under consideration from other types they resemble through comparison and contrast; but they are not the only procedures the visitor employs in the attempt to decide what sophistry and statesmanship are.

There is another aspect of the two procedures that calls for consideration. As mentioned above, some critics, such as Stanley Rosen, Drew Hyland, and Francisco Gonzales, have objected to the procedures on the grounds that they, supposedly, constitute a 'value neutral' method that leaves considerations of worth and honor out of the picture when considering what sophistry and statesmanship are.23 In the Sophist the visitor thus claims that his methodos or way of inquiry24 'honors all arts equally' (227b2), a claim he reiterates in the Statesman (266d4-10). But if sophist, philosopher, and statesman differ also on account of

\footnotetext{
${ }^{23}$ The first systematic articulation of this view is, to my knowledge, Rosen, Plato's Sophist. For scholars who follow Rosen, see note 6 and 7 above. Rosen's view was in some respects anticipated by Alexander Kojève in a letter from 1957 to Leo Strauss, see L. Strauss, On Tyranny - Corrected and Expanded Edition (Chicago: Chicago University Press, 2013), pp. 282-283, see also p. 288. But where Rosen seems to regard the visitor as a mixture of an analytic philosopher and a modern social scientist, Kojève sees him as Plato's ironic portrait of Eudoxus. It is interesting to note that Strauss, the teacher of Rosen, does not share Kojève's negative evaluation of the visitor, see Strauss, On Tyranny, pp. 292-293. The claim that the method is 'value-neutral' ultimately derives from the view of the method argued for in Stenzel, Studien zur Entwicklung, see especially pp. 27-30.

${ }^{24}$ I render the Greek methodos as 'way of inquiry' in order to avoid the modern connotations the word 'method' has; in contrast to a modern conception of method, according to which it is a neutral procedure that can be used to solve any question, a methodos is essentially a path or route that may be followed in order to track down what is sought in an inquiry.
} 
their differing worth, as Socrates suggests at the beginning of the Statesman (257b2-4), it could be objected that one cannot distinguish them adequately through this way of inquiry.25 To assess whether this line of criticism is justified, we need to take a closer look at the passage where the visitor explains why his way of inquiry 'honors all arts equally'. This is how the visitor explains its alleged 'value-neutrality':

'the rational way of inquiry happens to care neither more nor less for sponging than for drinking medicine, for whether the one type of cleansing benefits us a little or the other a lot. For the sake of acquiring understanding (tou ktêsasthai heneka noun), namely, when trying to apprehend what is akin and not akin in all the types of expertise (pasôn technôn to syngenes kai to mê syngenes), it honors them all equally in relation to this [that is, whether they are akin or not] (timai pros touto ex isou pasas) and it does not, in respect of their likeness (kata tên homoiotêta), consider some any more ridiculous than others, nor has it ever regarded one who clarifies hunting through the general's expertise as more august than one who does so through lousecatching but mostly as more conceited.' (Soph. 227a7-b6)

Despite appearances to the contrary, the visitor is not suggesting that his way of inquiry disregards worth simpliciter and puts all types of expertise on a par. He only claims that it honors all arts equally as regards their likeness and explains that this is a consequence of the aim of the inquiry, to apprehend kinship and lack of kinship between kinds of expertise. It does not follow that the way of inquiry will not allow one to accord more honor or worth to one kind of expertise than to another, only that one in order to do so must be able to point to a relevant difference between them.

\footnotetext{
${ }^{25}$ See Gonzales, 'His Master's Voice?', pp. 165-168, p. 170; see also Rosen, Plato's Statesman, pp. 10-11.
} 
By proceeding in this way, the visitor dispenses with common or 'everyday' evaluations of various types of expertise, as his example of the general and the louse-catcher makes clear. For a general is commonly regarded as worth more than a louse-catcher, but in so far as both may be said to exemplify hunting, they stand on a par as far as the way of inquiry is concerned.26 If one wished to argue that the general is nevertheless worth more than the louse-catcher, one would therefore have to specify why his work is, after all, different. It is important to note, however, that the visitor is not suggesting that no such difference exists, nor that the general is not worth more than the louse-catcher; all he states is that with regard to what they have in common, the activity of hunting, the way of enquiry honors them equally.

This way of proceeding is motivated, we may assume, by the initial problem pointed to by Socrates, that philosophers are commonly confused with sophists and statesmen and are evaluated differently by different people. In order to understand why they are confused and to argue that this is a confusion rather than a justified identification, it seems necessary to decide both their kinship and their difference, precisely what is investigated by the visitor's way of inquiry. Moreover, if the three types of expertise should be accorded different worth, as Socrates suggests, while ordinary conceptions of their worth are

\footnotetext{
${ }^{26}$ At a later point in the Sophist, the visitor explains that the ability to divide according to kinds (genê) without regarding the same form as different or a different form as the same belongs to dialectic (Soph. 253d1-3), while he in the Statesman explains that people who lack this ability throw things that are different together because they appear alike (Pol. 285a4-6). These passages form parts of general descriptions of dialectic, but we may assume that they have a specific bearing on this basic problem of the two dialogues, since sophist, statesman and philosopher are, after all, referred to as kinds at the beginning of the inquiry (genê; Soph. 217a8-9).
} 
ambiguous, it seems reasonable that such an evaluation should be based on a firm understanding of the ways in which their respective work differ from each other.

To sum up, against scholars who regard the visitor's way of inquiry as a 'valueneutral' method and see this as an indication of Plato's ironic distance to the visitor, it has been argued that the procedures of collection and division are presented in the Sophist and the Statesman as genuinely useful, are used specifically for the purpose of investigating kinship and difference between types of expertise, and that this investigation does not preclude the visitor from according different worth to various types of expertise so long as they can be shown to be different. That this is a correct understanding of the procedures may be illustrated through a brief consideration of some initial divisions found in the Statesman and a central passage in the Sophist discussing a so-called noble type of sophistry. These passages will also prove important when we turn to the question how the statesman compares with the philosopher as regards worth.

In the Statesman, the visitor begins his inquiry by distinguishing two kinds of knowledge (258e4-6), one aimed at action, the other solely at understanding: Types of expertise such as arithmetic are identified as sub-types of the latter kind and regarded as akin (sungenes) because they do not involve actions (258d4-6), while types of expertise such as carpentry are identified as sub-types of practical knowledge because their knowledge lies inherent in their actions (258d8-e2). Compared to these two kinds of expertise, political expertise, the interlocutors agree, belongs more properly within the kind of knowledge directed merely at understand (259c10-d2). The visitor nevertheless proceeds to suggest that political expertise differs from other types of knowledge directed at understanding on the grounds that it not only judges the objects it is set over like all such types of knowledge but also issues orders about what to do and how to act on the basis of its judgements (260a1-7). 
For political expertise is, as the visitor proceeds to make clear, a kind of direction-giving expertise that, in contrast to other types of direction-giving expertise such as that possessed by heralds, seers and the like, is based on personal understanding rather than the thoughts of others (260c6-e9). But in contrast to the understanding-based, direction-giving expertise of for instance a master architect that is set over soulless entities, political expertise is directed at living beings and is for that reason more noble (261c7-d2).

This overview demonstrates four points concerning collection and division. First, the procedures are used to identify groups of expertise by collecting and dividing them 27 in accordance with likenesses and differences for the purpose of deciding what types of expertise political expertise is most closely related to. Second, the inquiry is guided by a kind of presupposition concerning political expertise that comes to expression each time the interlocutors decide where to place political expertise; for they would not be able to decide that it resembles knowledge directed at understanding more than practical knowledge or that it differs from other types of knowledge directed at understanding because it issues commands if they knew nothing about it prior to the inquiry. Third, the visitor evaluates political expertise and other types of command-giving expertise treating of inanimate objects when setting them off from each other; the former is, as he states, more noble (gennaioteron; 261c9) than architecture, the implication being that types of expertise treating of living things are more important than types of expertise that do not. Fourth, this evaluation does not seem

\footnotetext{
${ }^{27}$ That collection is used throughout an inquiry proceeding through collection and division, and not just at its beginning as is commonly supposed, is argued convincingly in D. Henry, 'A Sharp Eye for Kinds: Plato on Collection and Division', Oxford Studies in Ancient Philosophy (2011), pp. 229-55.
} 
to result from collection and division; that types of expertise directed at what is ensouled are more noble than those that are not simply seems to be taken for granted by the visitor.

The same picture of collection and division emerges from a passage on the noble sophist found in the Sophist (226b2-230e5). Here the visitor sets out (226b2-c8) from a general type of expertise preoccupied with separation that he divides in two on the grounds that some types of separating expertise separate like from like, others worse from better (226d1-3). The latter he terms the purifying part of the separating expertise (226e1) and in the remainder of the passage he is preoccupied with sub-dividing this expertise, a procedure that terminates when he reaches the 'most important and lordly' type of cleansing (230d7-9), education through refutation. Since collection and division is also preoccupied with separation, we may assume that the visitor at the same time aims at illuminating his own way of proceeding, an impression strengthened by the fact that the remarks on method concerning worth and likeness discussed above is found in the passage under consideration.

If the point of these remarks were that all types of expertise should be regarded as being on a par, the visitor would have to think of the various types of purification he identifies in the passage as being equal in rank.28 This is not the case. Instead he separates inferior types of purification off from more important ones, i.e. he performs a kind of purification on the purifying kind of expertise, as the following summary of the passage makes clear. When he has separated the purifying expertise from the other type of separating expertise, the visitor divides purification in two: one type is directed at the body, the other at the soul (226e5-227c6). He then divides the latter, which has to do with virtue and vice (227d4-11), into punitive expertise (229a5) and teaching (229a10) since vice, according to

\footnotetext{
${ }^{28}$ This inference is made in Gonzales, 'His Master's Voice?'.
} 
the visitor, can be divided in two: one type is like sickness and civil war (228a1-b10), another, termed ignorance, results from a soul's inability to acquire truth (228c1-d11). Focusing on ignorance and its cure, teaching, the visitor next distinguishes between craft-teaching and education (paideia; 229d1-3), a division based on the claim that there are two types of ignorance, the lack of positive knowledge, on the one hand, and the state of believing that one knows what one does not (229c5), on the other. The latter is said to be 'great and grievous', equal to all other parts of ignorance in weight (229c1-3). The visitor finally divides education into traditional admonition (229e4-230a3) and purification through the use of refutation (230a5-d4) and identifies the latter as the 'most important and lordly' type of purification (230d7-8).

As the final divisions of ignorance and types of education make clear, the visitor regards one side of his divisions as more important than the other. His overall aim in the passage is to separate the vice of believing to know what one does not from all other types of vice and the type of education treating this vice, educational purification through refutation, from all other types of teaching. It is this aim that determines the visitor's initial distinction between purification and other types of separation and, in particular, the purification directed at souls from other types of purification. For the purification of souls is more important than every other type of purification, a view that is also underlined by the visitor's claims that refutation is the greatest and most lordly type of purification and that one who has not been tested by it is left 'uneducated and ugly in the very respect in which the person who is genuinely going to be happy ought to be his cleanest, purest, and most beautiful.' (230d9-e4). In other words, the visitor identifies refutational education and the removal of the false belief that one knows what one does not as a prerequisite for human happiness or flourishing and accords this type of education a clear priority over every other type of teaching and education. 
As should be clear, moreover, the education the visitor describes in this passage is in fact the one endorsed by Socrates,29 a fact that also explains why the visitor is reluctant to call its practitioner a sophist (231a1) and opts to call the expertise possessed by this practitioner 'sophistry noble in origin' (hê genei gennaia sophistikê; 231b8), that is, sophistry as it should be, and not as it is.

Here we again we see that the evaluation of vice and education expressed by the visitor is not the result of collection and division. We may nevertheless say that it comes to expression through collection and division in the precise sense that collection and division help explicate the objective basis grounding this evaluation. Rather than simply asserting that refutation is the highest kind of education and purification, the visitor may thus be said to provide a causal explanation for this view: since there are different types of vice, some more grievous than others, and since there are different types of teaching and education directed at them, some more important and effective than others, one is justified in claiming that refutational education is the most important type of purification.

\section{Settling the worth of philosopher and statesman through their work}

Neither the Sophist nor the Statesman present us with a full account of the philosopher. This may explain why we do not find a full discussion of the worth of sophist, statesman, and philosopher in them either. For as Socrates' statement at the beginning of the Statesman

\footnotetext{
${ }^{29}$ G. B. Kerferd, 'Plato's Noble Art of Sophistry', Classical Quarterly 4 (1954), pp. 84-90, argued for the view that the noble sophist described in the passage was it Socrates but rather a type of sophist Plato regarded as genuinely valuable, important for his own philosophical development. The article is criticized convincingly in J. R. Trevaskis, 'The sophistry of noble lineage', Phronesis 1 (1955), pp. 36-49.
} 
$(257 \mathrm{~b} 2-4)$ makes clear, the question is not what honor or worth each type should be accorded in isolation, but rather how much honor each should be accorded when seen in relation to the other two, and deciding this question seems to require that we know both what each of the three are and how they differ from each other. The two dialogues nevertheless present us with several hints as regards the visitor's evaluation of the three types, hints that at the same time point to various reasons for insisting that the three types truly differ from each other. It is clear that the visitor does not accord any worth to sophistry. At the end of the Sophist, he and his interlocutor agree that the sophist is a mere imitator of the wise person (Soph. 268b10-c4), an agreement that harkens back to claims made earlier by the visitor to the effect that the sophist merely dabbles in pseudo-education (223b4) and possesses no real knowledge; the only expertise possessed by sophists is an uncanny ability to debate about everything with everyone, an ability that helps them give the impression especially to young people of being absolutely wise $(232 \mathrm{e} 6-233 \mathrm{~b} 7,234 \mathrm{c} 2-7)$. The reason people accord sophists any worth, the visitor thus seems to be suggesting, is because they confuse sophists with the wise people they imitate. If philosophy can be defined as a quest for wisdom born out of the realization that one lacks knowledge concerning the most important matters, as Plato's Socrates suggests in several dialogues, sophistry can be regarded as a shadowy reflection of this quest that has no real worth, since it neither possesses knowledge of that which truly matters nor encourages others to seek it.

Political expertise, on the other hand, is accorded real worth by the visitor and regarded as a genuine expertise in its own right. More specifically, the visitor regards political expertise as a knowledge-based, direction-giving expertise set over living beings (Pol. 260c1261d2) whose function it is to care for human beings in so far as they live together in communities (see 267a8-c3 with 275c9-e9). And in contrasts to other types of care directed at 
such communities, political expertise or the art of ruling communities extends it care to the whole human community (276b8-c2). This care comes to expression, ideally at least, through the statesman's activity of weaving various aspects of the human community into a true whole (305e2-6). In particular, the statesman oversees that those citizens who by nature lean toward courage are made more moderate, and those who by nature lean toward moderation are made more courageous, even if these two character-traits on their own tend to stand in opposition to each other (308d1-310a5). The reason why the taming or transformation of these two natural character-traits is so important is that they, if they are allowed to develop freely and on their own, tend to destroy cities; for those who are inclined to be courageous tend to become too aggressive and unjust if left on their own and steer the city toward unnecessary wars, and those who are inclined to be moderate and orderly tend to become too modest and cautious and make their city too docile and slavish (307e1-308a9, 310d6-311b5) The visitor's description of the way in which the statesman accomplishes this transformation of natural courage and moderation in the citizens is dense and complex and a mere outline of his argument will have to suffice in the present context. The overall claim he makes is that political expertise can accomplish such a transformation by instilling in the citizens a true and steadfast 'opinion about beautiful and just and good things' (309c5-d4), since the possession of such an opinion, the visitor asserts, will make courageous souls more tame and just (309d10-e2) and transform orderly natures into becoming truly moderate and wise (ontôs sophron kai phronimon), at least as far as a constitution is concerned (hôs ge en politeiai; 309e5-7). And the way in which the statesman will instill this true opinion is, apparently, through laws (310a1-2).

It thus seems that the real work of the statesman consists in bringing about virtue in the citizens and that political expertise is, in this sense, the capstone of an 
educational system aimed at molding and modifying the natural inclinations of human beings (see 308d1-e2). The statesman will thus differ from the sophist by the fact not only that he or she possesses a genuine expertise but also more specifically by the fact that political expertise is preoccupied with real education and truly cares for virtue. For that reason, the sophist can be regarded not only as an imitator of the philosopher, but also as an imitator of the one who possesses true political expertise (see 303b8-c5).

Despite of the praise involved in the visitor's determination of true political expertise, however, he also indicates a certain limit to it. For while it is preoccupied with instilling virtue in the citizens, it tends to focus only on two virtues, courage and moderation. These virtues are perhaps most important for the survival of the city, but they are not necessarily the virtues most important for the flourishing of the individual. It is true that the visitor also claims that political expertise, by installing a true opinion about beautiful, just and good things, make courageous human beings more just, and orderly human beings truly moderate and wise, at least as far as a constitution is concerned. But making courageous people more just may not amount to making them truly just, and what counts as being truly moderate and wise as far as a constitution is concerned may fall short of true moderation and wisdom. Moreover, while the implication of the visitor seems to imply that true statesmen possess genuine knowledge, it seems doubtful that they aim at passing this knowledge on to their subjects. For, it may be argued, all that can be instilled in others through laws and customs are true opinions, as the visitor also indicates, and if real virtue ultimately depends on insight, the statesman will not be able to nurture such virtue in his or her subjects.

Moreover, as the visitor made clear in the Sophist, human flourishing ultimately depends on the purifying type of education practiced by Socrates. We may suggest that this is because real virtue cannot be acquired in isolation from the examined life Socrates claims is 
the only one worth living for a human being (Apo. 38a5-6). Exhorting people, individually, to live such a life, however, is not the task of the statesman. For political expertise is by necessity directed at the human community, not at individuals qua individuals, precisely because it operates through general laws, customs, and institutions, a fact recognized by the visitor (Pol. 294e9-295b5). It is rather the task of the philosopher, understood as an individual who cares for other individuals and for that reason engages with them in conversation. According to the visitor, political expertise may thus be necessary for the good society and perhaps also for human flourishing. But it is not sufficient for the latter - for such flourishing also requires philosophy. 